\title{
Nietypowa lokalizacja złogów amyloidu w szpiczaku plazmocytowym
}

\section{Unusual localisation of amyloid deposits in plasma cell myeloma}

\author{
Jacek Szymańczyk ${ }^{1}$, Ryszard Pogłód ${ }^{2}$, Maria Kraj ${ }^{3}$, Agnieszka Michalska ${ }^{1}$, \\ Monika Prochorec-Sobieszek ${ }^{3}$, Janusz Szymańczyk ${ }^{4}$, Krzysztof Warzocha ${ }^{5}$ \\ ${ }^{1}$ Klinika Dermatologiczna, Warszawski Uniwersytet Medyczny \\ ${ }^{2}$ Zakład Transfuzjologii, Instytut Hematologii i Transfuzjologii \\ ${ }^{3}$ Zakład Diagnostyki Hematologicznej, Instytut Hematologii i Transfuzjologii \\ ${ }^{4}$ Warszawski Uniwersytet Medyczny \\ ${ }^{5}$ Klinika Hematologii, Instytut Hematologii i Transfuzjologii
}

\begin{abstract}
Streszczenie
U 68-letniego mężczyzny ze szpiczakiem plazmocytowym (PCM) (wariant: choroba tańcuchów lekkich $\kappa)$, leukopenia oraz wspótistniejaca choroba niedokrwienna serca, po 4 latach od rozpoznania nowotworu stwierdzono guzkowe nacieczenie dolnej wargi. Zmiane usunieto chirurgicznie. $W$ badaniu histopatologicznym usuniętego materiatu wykazano, że tworzyty go ztogi amyloidu. Brak dostępności inhibitorów proteasomu spowodowat, że od rozpoznania pacjent otrzymywat chemioterapie ztożona gtównie $z$ cyklofosfamidu $i$ deksametazonu. W wyniku leczenia systemowego uzyskano czéściowa remisje $i$ stabilizacje PCM. W dalszej obserwacji wystapity zaostrzenie choroby wieńcowej, zawat serca i cięzka niewydolność krażenia, a w końcowym okresie - progresja PCM. Leczenie chirurgiczne guza amyloidowego byto powiktane upośledzonym gojeniem wargi. Przypadek ten wskazuje na możliwość wystapienia w przebiegu PCM guzów zawierajacych ztogi amyloidu o nietypowej lokalizacji.
\end{abstract}

Słowa kluczowe: amyloidoza, amyloidoma, szpiczak plazmocytowy, choroba łańcuchów lekkich, amyloidoza wargi

Hematologia 2016; 7, 1: 85-92

\begin{abstract}
Amyloid deposits in the lower lip were found in a 68-year-old patient with plasma cell myeloma $(P C M)$ (variant: $\kappa$ light chain disease), leukopenia and coexisting ischemic heart disease four years since the diagnosis of malignancy. The lesion was surgically removed. Inaccessibility of proteasome inhibitors resulted that the patient was treated mainly with cyclophosphamide and dexamethasone. This systemic treatment resulted in partial remission and stabilization of PCM. During further observation the patient experienced severe exacerbation of his ischemic heart disease, heart infarct and severe heart failure as well as PCM progression. Surgical treatment of amyloid tumor was complicated by impaired lip healing. This case indicates that tumors containing amyloid deposits in unusual localisation are likely to occur in the course of PCM.
\end{abstract}

Key words: amyloidosis, amyloidoma, plasma cell myeloma, light chain disease, lip amyloidosis

Hematologia 2016; 7, 1: 85-92

Adres do korespondencji: Ryszard Pogłód, Zakład Transfuzjologii, Instytut Hematologii i Transfuzjologii, ul. Indiry Gandhi 14, 02-957 Warszawa, tel. 223496 556, e-mail: rpoglod@ihit.waw.pl 


\section{Wprowadzenie}

Amyloidoza związana $z$ istniejącą dyskrazją plazmocytową, tak zwana amyloidoza łańcuchów lekkich (AL, light chain amyloidosis), jest najczęstszą postacią amyloidozy układowej [1, 2]. W przebiegu szpiczaka plazmocytowego (PCM, plasma cell myeloma) może występować u $25 \%$ chorych [3]. Jest to typ amyloidozy związany $z$ nadprodukcją łańcuchów lekkich immunoglobulin, które po odpowiedniej modyfikacji ich N-końcowego fragmentu i przejściu w stan nierozpuszczalny tworzą zrąb odkładających się włókien amyloidu. Zarówno powody i mechanizm odkładania się włókien amyloidu, jak i skłonność do zajmowania określonych narządów nie są jeszcze dobrze poznane [2].

Amyloidoza AL ma najczęściej charakter układowy, ale może też występować wyłącznie miejscowo. Obserwuje się wtedy izolowane nacieki bądź guzy zawierające amyloid (tzw. amyloidoma) o różnej lokalizacji. Odosobnione guzy występują także w innych postaciach amyloidozy [4-7]. W ich patogenezie istotną rolę zdaje się odgrywać miejscowa stymulacja antygenowa $[4,7,8]$. Dlatego najczęściej zmiany te występują $\mathrm{w}$ miejscach narażonych na kontakt $z$ antygenem, tj. błonach śluzowych dróg oddechowych i przewodu pokarmowego $[2,9,10]$.

Dość często w przebiegu amyloidozy dochodzi do powstawania zmian w obrębie jamy ustnej, a zwłaszcza charakterystycznego powiększenia języka (macroglosia) [10-15]. Rzadko jednak opisywano przypadki złogów amyloidu wokół naczyń tętniczych jamy ustnej, a nacieczenie czy też zmiany o charakterze guzów amyloidowych w obrębie warg stanowią wyjątkową rzadkość $[16,17]$. W pracy opisano przypadek chorego na PCM i ze zmianami o typie amyloidozy w obrębie naczyń wargi dolnej.

\section{Opis przypadku}

Pacjent w wieku 68 lat, leczony w ośrodku kardiologicznym $z$ powodu rozpoznanej 6 lat wcześniej choroby niedokrwiennej serca (IHD, ischemic heart disease), został przyjęty 23 marca 2004 roku do Kliniki Hematologii Instytutu Hematologii i Transfuzjologii (IHT) w celu przeprowadzenia diagnostyki leukopenii. Nie zgłaszał dolegliwości. W badaniu morfologii krwi, spośród odchyleń od stanu prawidłowego, stwierdzono zmniejszoną do 2,0 G/1 liczbę krwinek białych (WBC, white blood cells) (w ich rozmazie: granulocyty obojętnochłonne $48 \%$, obojętnochłonne o jądrze pałeczkowatym $6 \%$, kwasochłonne $-2 \%$, limfocyty $-44 \%$ ) oraz mierną niedokrwistość (stężenie hemoglobiny [Hb] $11,7 \mathrm{~g} / \mathrm{dl}$ ). W badaniu histopatologicznym szpiku stwierdzono bogatokomórkowy szpik nacieczony w $70 \%$ przez plazmocyty CD38 + wytwarzające lekkie łańcuchy $\kappa$. W badaniu białek surowicy wykryto śladowe ilości monoklonalnych łańcuchów lekkich $\kappa$; stężenie wolnych lekkich łańcuchów $\kappa(\kappa \mathrm{FLC}$, $\kappa$ free light chain) w surowicy wynosiło $109,00 \mathrm{mg} / \mathrm{l}$, wolnych lekkich łańcuchów $\lambda$ ( $\lambda \mathrm{FLC}, \lambda$ free light chain) $-9,78 \mathrm{mg} / \mathrm{l}$, a stosunek $\kappa \mathrm{FLC} / \lambda \mathrm{FLC}$ wyniósł 11,10. W badaniu ogólnym moczu wykazano obecność $\kappa \mathrm{FLC}$ w stężeniu $30 \mathrm{mg} / \mathrm{dl}$, a ich dobowe wydalanie wynosiło $0,84 \mathrm{~g}$. W przeglądowym badaniu radiologicznym nie zobrazowano zmian osteolitycznych. Sylwetka serca wykazywała konfigurację lewokomorową. Wyniki badań biochemicznych w surowicy krwi były prawidłowe. Rozpoznano wówczas PCM w okresie IA wedługg klasyfikacji Durie-Salmona.

Ze względu na brak dostępności w tym czasie inhibitorów proteasomu pacjent rozpoczął chemioterapię złożoną z cyklofosfamidu $(\mathrm{Cy}) \mathrm{w}$ dawce $1000 \mathrm{mg}$ $\mathrm{w}$ jednorazowym wlewie dożylnym (i.v., intravenous) i deksametazonu (DEX, dexamethasone) $\mathrm{w}$ dawce $12 \mathrm{mg}$ /dobę podawanego przez 4 dni. Chemioterapia ta była główną metodą leczenia pacjenta. Planowana $z$ zamiarem podawania w odstępach miesięcznych była jednak prowadzona dość nieregularnie ze względu na liczne epizody zaostrzenia IHD i hospitalizacje pacjenta poza IHT. W maju 2005 roku u chorego stwierdzono prawidłowe stężenie $\mathrm{Hb}(14,0 \mathrm{~g} / \mathrm{dl})$ i wzrost WBC do $3,2 \mathrm{G} / 1$, a po 8 cyklach leczenia, we wrześniu 2005 roku, nastąpiła pełna normalizacja morfologii krwi (stężenie Hb 14,3 g/dl, WBC 4,0 G/l, liczba krwinek płytkowych $184 \mathrm{G} / 1$ ). W lutym 2006 roku w badaniu histopatologicznym stwierdzono zmniejszenie się nacieku plazmocytowego szpiku do 15\% $z$ zachowanym prawidłowym utkaniem krwiotwórczym oraz nieznaczne wydalanie białka Bence'a-Jonesa $z$ moczem $(0,21 \mathrm{~g} / \mathrm{d}$.), co wskazywało na uzyskanie remisji częściowej według kryteriów IMWG (International Myeloma Working Group)/ /EBMT (The European Group for Blood and Marrow Transplantation). Utrzymywały się satysfakcjonujące wartości $\mathrm{Hb}(12,8 \mathrm{~g} / \mathrm{dl})$ i WBC $(3,3 \mathrm{G} / \mathrm{l})$, a w badaniu RTG kośćca w listopadzie 2006 roku nadal nie stwierdzano zmian osteolitycznych. Do tego czasu pacjent otrzymał 8 kolejnych cykli chemioterapii $\mathrm{Cy} z$ DEX oraz 3 cykle złożone $z$ melfalanu (MEL) i prednizonu (PDN) doustnie.

Do połowy marca 2007 roku pacjent pozostawał w dobrym stanie ogólnym i otrzymał jeden kurs $\mathrm{Cy}$ z DEX. Wkrótce jednak nastąpiło zaostrzenie IHD 
i w kwietniu 2007 roku przebył on zawał serca, który leczono angioplastyką $z$ wszczepieniem stentu. W późniejszym okresie pacjent przebył jeszcze kilka epizodów niedokrwienia mięśnia sercowego wymagających długotrwałych hospitalizacji. W ich następstwie wystąpiła ciężka niewydolność serca (III/IV klasa wg NYHA [New York Heart Association]). Ze względu na zły stan ogólny pacjent przez 10 miesięcy przebywał głównie w domu lub był hospitalizowany w ośrodkach kardiologicznych. Nie otrzymywał w tym okresie chemioterapii. Obserwowano nasilenie niewydolności krążenia oraz znacznego stopnia wyniszczenie.

Pouzyskaniu poprawy stanu ogólnego pacjent był ponownie hospitalizowany w Klinice Hematologii IHT w sierpniu 2008 roku. W badaniu cytologicznym aspiratu szpiku (nie uzyskano diagnostycznego materiału $z$ trepanobiopsji) wykazano nacieczenie plazmocytowe obejmujące $26 \%$ komórek jądrzastych ubogokomórkowego szpiku. W badaniu immunofiksacji moczu stwierdzono obecność $\kappa$ FLC. W morfologii krwi obserwowano znaczną leukopenię $(1,6 \mathrm{G} / 1)$ oraz niedokrwistość (stężenie $\mathrm{Hb}$ $10,1 \mathrm{~g} / \mathrm{dl}$ ). W listopadzie 2008 roku w trakcie kolejnej chemioterapii Cy z DEX u pacjenta wystąpił ból w klatce piersiowej. W badaniu elektrokardiograficznym nie wykazano cech niedokrwienia, aktywność troponin sercowych w surowicy nie była zwiększona, a w badaniu radiologicznym klatki piersiowej nie stwierdzono zmian osteolitycznych. Pacjenta przeniesiono do ośrodka kardiologicznego.

W grudniu 2008 roku podczas kontrolnej wizyty w Klinice Hematologii IHT wyniki morfologii krwi nie odbiegały od tych sprzed miesiąca (WBC 1,8 G/l, stężenie Hb 10,0 g/dl). Badanie ogólne moczu było prawidłowe, a w dobowej zbiórce moczu stwierdzono śladową ilość białka. Wyniki badań biochemicznych w surowicy krwi były prawidłowe. Natomiast w badaniu przedmiotowym pacjenta stwierdzono guz o litej, chrząstkowatej konsystencji, opalizujący i prześwitujący przez śluzówkę i zlokalizowany głęboko w obrębie tkanek miękkich dolnej wargi (ryc. 1). Pacjent negował wcześniejsze urazy, skaleczenia, procesy zapalne czy wykwity opryszczkowe tej okolicy dolnej wargi, które by bezpośrednio poprzedzały wystąpienie stwierdzanej obecnie zmiany. Zdecydowano o operacyjnym usunięciu guza w Klinice Dermatologicznej Warszawskiego Uniwersytetu Medycznego. Ze względów kosmetycznych podjęto decyzję o próbie usunięcia guza od strony śluzówki jamy ustnej (ryc. 2). Po nacięciu śluzówki wypreparowano masę guza o wzmożonej spoistości zlokalizowaną wzdłuż przebiegu naczyń krwionośnych.
W trakcie preparowania guza nastąpiło masywne krwawienie, ponieważ guz obejmował duże naczynia dolnej wargi. Usunięta zmiana przypominała sznur czerwonych korali (ryc. 3). Badanie histopatologiczne wypreparowanej tkanki wykazało obraz typowy dla amyloidozy (ryc. 4).

W dalszej, już ambulatoryjnej, obserwacji u pacjenta stwierdzono upośledzone gojenie i bliznowacenie dolnej wargi, $z$ wytworzeniem bolesnego owrzodzenia w obrębie błony śluzowej. $Z$ tego powodu zaprzestał on doustnego przyjmowania pokarmów i stosowano żywienie parenteralne. Prowadzono miejscowe leczenie stomatologiczne. Nasiliło się wyniszczenie chorego. Od stycznia 2009 roku dalszy los pacjenta nie jest znany, gdyż na stałe wyjechał $z$ kraju. W wykonanym ex post barwieniu czerwienią Kongo preparatu szpiku z ostatniego badania histopatologicznego (luty 2006 r.), w ścianie drobnego naczynia wykazano obecność dyskretnych złogów amyloidu (ryc. 5).

\section{Dyskusja}

Manifestacja kliniczna amyloidozy w jamie ustnej może wystąpić w odsetku sięgającym $40 \%$ postaci pierwotnej AL. Dotychczas jednak, poza powiększeniem języka, opisano niewiele przepadków amyloidozy zlokalizowanej w obrębie jamy ustnej w przebiegu PCM [12-15]. Jeszcze rzadsze są przypadki lokalizacji złogów amyloidu wokół naczyń tętniczych w obrębie jamy ustnej [16]. Niezwykle rzadkie występowanie amyloidowego nacieku wargi sprawia, że taki guz przede wszystkim przywodzi na myśl nowotwór nabłonkowy, tj. raka wargi bądź nacieczenie plazmocytowe w przebiegu PCM, dlatego rozpoznanie amyloidoma stanowi zwykle duże zaskoczenie [17]. Takie umiejscowienie złogów może być trudne do zróżnicowania z procesami chorobowymi ślinianek [18]. Pacjenci najczęściej zgłaszają dolegliwości w postaci bólu śluzówek jamy ustnej, często potęgowanego przez używanie protez zębowych. Makroglosja i suchość jamy ustnej, prowadzące do dysfagii, są spowodowane odkładaniem się złogów amyloidu w języku i gruczołach ślinowych [19]. W badaniu przedmiotowym najczęściej obserwuje się dyskretne żółtawe guzki w obrębie języka, podniebienia oraz błony śluzowej jamy ustnej.

Wykrycie u pacjenta złogów amyloidu w wardze implikuje pytanie, czy guz ten stanowił pojedynczą odosobnioną zmianę miejscową, czy był przejawem uogólnionej amyloidozy AL bądź nastąpiła ewolucja $z$ asymptomatycznej amyloidozy w postać objawową. Z powodu przerwania obserwacji 


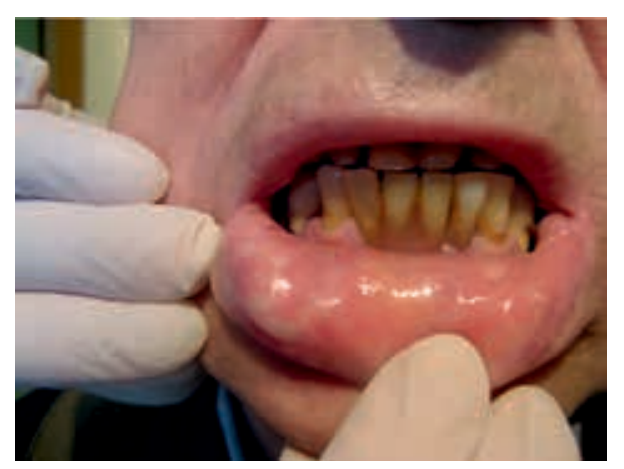

Rycina 1. Obraz kliniczny - lity guz, lekko opalizujący i prześwitujący przez śluzówkę dolnej wargi

Figure 1. Clinical manifestation: solid tumor, slightly opalescent, seen through mucosa of lower lip

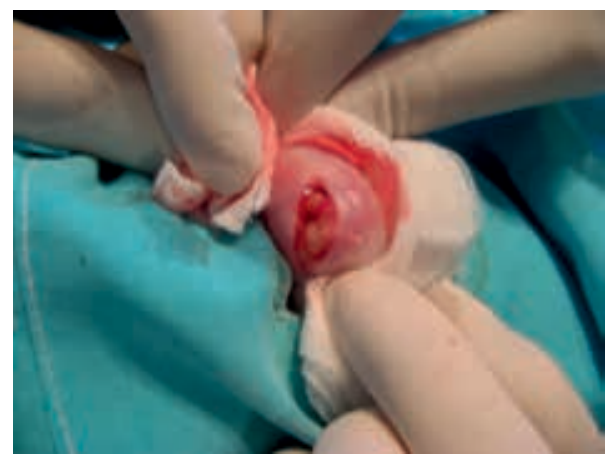

Rycina 2. Operacyjny dostęp do masy guza od strony śluzówki jamy ustnej

Figure 2. Surgical access to the tumor from the mucosa of oral cavity

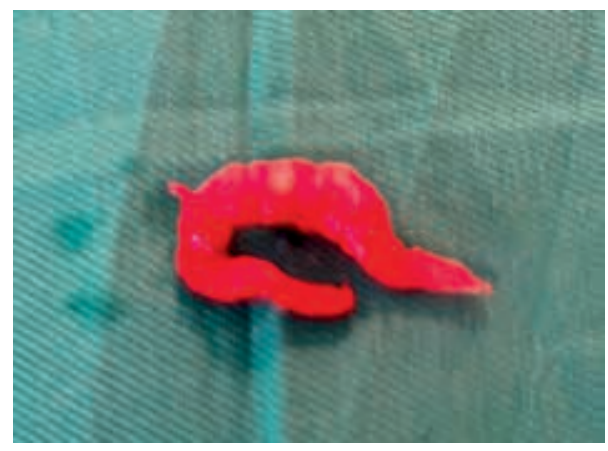

Rycina 3. Wypreparowany guz zbliżony kształtem do sznura korali

Figure 3. Surgically removed tumor in the shape of string of beads

po rozpoznaniu amyloidozy wargi $\mathrm{u}$ tego pacjenta nie była już możliwa diagnostyka amyloidozy ukła-

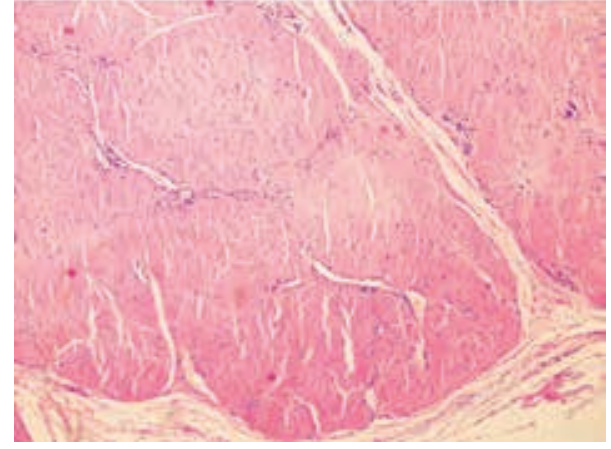

Rycina 4. Obfite bezpostaciowe złogi odpowiadające złogom amyloidu w wycinkach z guza (barwienie hematoksyliną-eozyną, powiększenie $100 \times$ )

Figure 4. Tumor biopsy: abundant amorphous deposits corresponding to amyloid deposits (hematoxylin-eosin staining, magnification $100 \times$ )

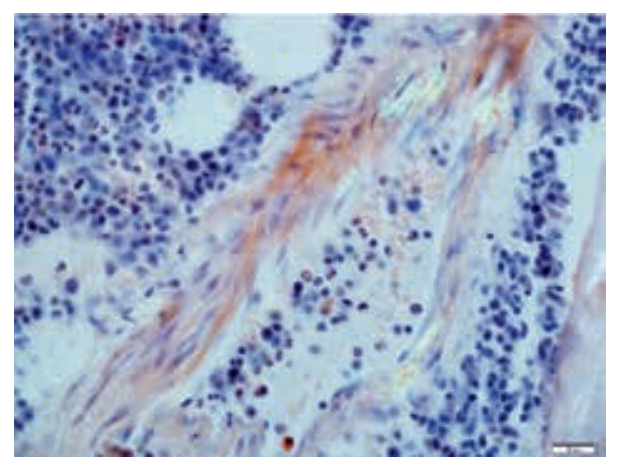

Rycina 5. Dyskretne złogi amyloidu wykazujące zielone świecenie w świetle spolaryzowanym w trepanobiopsji szpiku w ścianie naczynia krwionośnego (barwienie czerwienią Kongo, powiększenie $400 \times$ )

Figure 5. Bone marrow biopsy: fine amyloid deposits in the blood vessel wall showing a green luminescence in polarized light (Congo red staining, magnification $400 \times$ )

dowej rutynowymi metodami, takimi jak biopsja tkanki tłuszczowej, śluzówki odbytu czy szpiku, w połączeniu $z$ dokładną oceną obrazową i czynnościową poszczególnych narządów, a zwłaszcza serca $[2,3,10,11]$.

Podejrzenie amyloidozy mogą nasuwać pogorszenie czynności określonego narządu, najczęściej nerek i serca, rzadziej wątroby, wyniszczenie, a także postępujące bez uchwytnej przyczyny pogarszanie stanu ogólnego. Występują też zaburzenia neurologiczne, uporczywa hipotonia, przewlekłe biegunki, obrzęki. Zmiany amyloidowe mogą również występować w skórze i błonach śluzowych. Dość charakterystycznymi objawami 
są powiększenie języka, wylewy okołooczodołowe i zespół cieśni nadgarstka [1, 2, 3, 5, 11]. Symptomatologia w amyloidozie AL bez rozrostu szpiczakowego nie różni się od amyloidozy wikłającej PCM $[2,3,10,11]$.

Oceniając przypadek ex post, można przyjąć, że objawy kliniczne i wykonane badania laboratoryjne w okresie obserwacji chorego nie wskazywały na obecność amyloidozy układowej. Nie było podstaw, aby u pacjenta podejrzewać amyloidozę nerek i prowadzić diagnostykę w tym kierunku. Przez cały okres obserwacji u chorego wykrywano śladowe ilości białka w moczu, a wskaźniki biochemiczne wydolności nerek w surowicy pozostawały prawidłowe. Stężenie FLC w moczu w trakcie obserwacji było niewielkie. Pacjent nie wykazywał też innych charakterystycznych dla amyloidozy objawów. Choć zmiana była umiejscowiona w obrębie jamy ustnej, to nie stwierdzano makroglosji. Również współistniejąca $z$ PCM choroba serca nie wskazywała na amyloidozę. Należy podkreślić, że IHD poprzedzała o kilka lat rozpoznanie PCM, a jej przebieg, powikłany zawałem serca, był bardzo typowy i nie budził wątpliwości diagnostycznych. Od początku obserwacji stwierdzano także powiększenie lewej komory serca. Choroba niedokrwienna serca i zawał serca nie są charakterystyczne dla amyloidozy. Znaczne zaostrzenie w ostatnim okresie obserwacji IHD również było etiologicznie jednoznaczne. Dopiero dołączenie się objawów niewydolności krążenia mogłoby przemawiać za nałożeniem się zmian skrobiawiczych na już istniejącą patologię serca. Obserwacja ta, wraz ze stwierdzanym u chorego w ostatnim okresie wyniszczeniem oraz w połączeniu Z wykryciem bardzo dyskretnych włókien amyloidu w ścianie naczynia krwionośnego $\mathrm{w}$ badaniu ex post w szpiku z 2006 roku, mogą wskazywać na wcześniejszy początek amyloidozy — jeszcze przed wystąpieniem nacieczenia amyloidowego wargi.

Przypadek ten nakazuje zwrócenie uwagi na problem asymptomatycznej amyloidozy w przebiegu PCM. U 12-15\% chorych na PCM występuje postać jawna klinicznie. Jednak w stosunkowo dużym odsetku przypadków jej przebieg jest bezobjawowy i mimo odkładania złogów amyloidu w tkance podskórnej, szpiku i innych ważnych życiowo narządach nie dochodzi do zaburzeń ich czynności. O ich obecności świadczą wyniki wykonywanych u chorych na PCM badań tkanki tłuszczowej i szpiku, które są dodatnie, odpowiednio u $31 \%$ i $10 \%$ chorych na PCM [3, 11, 20, 21].

$\mathrm{W}$ świetle danych $\mathrm{z}$ końcowego okresu obserwacji pacjenta mało prawdopodobne wydaje się, aby zmiana stanowiła zlokalizowaną postać amyloidozy.
Odosobnione guzy typu amyloidoma, w przypadku nieobecności uogólnionej amyloidozy opisywano w różnych lokalizacjach anatomicznych, w tym płucach, układzie moczowo-płciowym, przewodzie pokarmowym, ośrodkowym układzie nerwowym, sutku, skórze i tkankach miękkich [4-7, 22]. $\mathrm{W}$ jednej $z$ analiz zlokalizowana amyloidoza stanowiła $12 \%$ na 606 przypadków amyloidozy [22]. Również $\mathrm{w}$ przebiegu nowotworów plazmocytowych opisywano zlokalizowane guzy typu amyloidoma bez obecności uogólnionej amyloidozy. Należy do nich zaliczyć zarówno przypadek izolowanego amyloidoma $\mathrm{w}$ obrębie kości krzyżowej w przebiegu PCM, jak i przypadek amyloidoma ściany klatki piersiowej współistniejący z odosobnionym guzem plazmocytowym kości [23, 24]. Jedynie u 15\% chorych z amyloidoma wykrywano obecność łańcucha lekkiego $\kappa$ lub $\lambda$ w materiale biopsyjnym $z$ guzów [22]. Sugeruje to, że w ich etiopatogenezie rolę może odgrywać miejscowe wytwarzanie amyloidu w wyniku stymulacji określonym antygenem. Dość spektakularny jest na przykład przypadek rozwinięcia się amyloidoma u chorego na cukrzycę w miejscu wstrzykiwania insuliny, bez obecności amyloidozy układowej [8]. Guzy tego typu nie ewoluują w kierunku uogólnionej amyloidozy [7, 9, 22].

U opisywanego pacjenta - zarówno w cytoplazmie plazmocytów szpiku, jak i w surowicy krwi - wykryto monoklonalny lekki łańcuch typu $\kappa$. Niektórzy autorzy wyrażają pogląd o pewnej odrębności guzów amyloidoma w odniesieniu do uogólnionej amyloidozy AL, uzasadniając ją częstszym występowaniem łańcucha lekkiego typu $\kappa$ w postaci zlokalizowanej, natomiast $\lambda \mathrm{w}$ układowej postaci amyloidozy $[9,20]$. $Z$ kolei w badaniach chorych z AL w przebiegu PCM nie wykazano częstszego występowania łańcucha lekkiego $\lambda$ [20]. Podobnie w innym badaniu dotyczącym amyloidozy w przebiegu PCM stwierdzano znacznie częstsze występowanie lekkiego łańcucha $\kappa$ (u $66 \%$ chorych) niż u chorych na PCM bez obecności amyloidozy, ale ta nadreprezentacja może wynikać $z$ częstszego występowania łańcucha $\kappa$ w PCM [3].

W kontekście omawianego przypadku należy rozważyć związek między wystąpieniem zmiany amyloidowej a procesem szpiczakowym i jego odpowiedzią na leczenie przeciwnowotworowe. U pacjenta stwierdzono amyloidozę wargi w 4 . roku leczenia PCM. Związek czasowy między rozpoznaniem PCM a wystąpieniem amyloidozy może zachodzić w różnym układzie. W części przypadków amyloidozę stwierdza się jednocześnie $z$ rozpoznaniem PCM bądź odosobnionego guza plazmocytowego [14, 15, 21, 23, 24], a u $10-15 \%$ 
pacjentów amyloidoza występuje w przebiegu rozpoznanego wcześniej PCM [11]. Natomiast ewolucja amyloidozy AL w PCM jest niezwykle rzadka. W okresie 35-letniej obserwacji wystąpiła jedynie u 6 na 1596 przypadków [11]. Trzeba jednak podkreślić, że relacja między tymi jednostkami chorobowymi jest bardziej złożona, gdyż zarówno amyloidoza AL, jak i PCM są przedstawicielami dość szerokiego kręgu gammapatii monoklonalnych. Kyle i wsp. [1] wykazali, że 85\% pacjentów $z$ amyloidozą AL spełnia kryteria rozpoznania różnych postaci dyskrazji plazmocytowych, a u pozostałych $15 \%$ nie ma cech klonalnego rozrostu plazmocytowego.

Rozpoznanie PCM u pacjenta nie budziło wątpliwości. W przebiegu choroby występowały nie tylko leukopenia, ale także niewielkiego stopnia niedokrwistość, nie stwierdzano natomiast zmian osteolitycznych, hiperkalcemii ani niewydolności nerek. W wyniku stosowanego leczenia uzyskano zarówno ponad 50-procentowe zmniejszenie odsetka plazmocytów w szpiku, jak i czasową normalizację morfologii krwi. Jednak w okresie pojawienia się $\mathrm{u}$ pacjenta nacieku wargi rozrost szpiczakowy uległ już progresji, ponieważ kilka miesięcy przed uwidocznieniem nacieku doszło zarówno do zwiększenia infiltracji plazmocytowej szpiku, jak i pogłębienia niedokrwistości i leukopenii. Wyniki analiz występowania amyloidozy zależnie od stanu i stopnia zaawansowania rozrostu szpiczakowego nie są jednoznaczne. $W$ jednym z badań wykazano, że w $47 \%$ przypadków w chwili pojawienia się zmian amyloidowych stwierdzano stabilizację rozrostu szpiczakowego, w $13 \%$ częściową lub lepszą odpowiedź, natomiast w $26 \%$ progresję [11]. Z kolei wyniki innej analizy wskazują na częstsze występowania zmian skrobiawiczych w zaawansowanym okresie III PCM bądź w okresie wznowy albo oporności na leczenie [3].

Leczenie przeciwnowotworowe pacjenta, ze względu na obciążenie kardiologiczne i leukopenię, składało się z podawanego cyklicznie Cy z DEX i kilkakrotnie - Mel z PDN. Nie odbiegało zatem od typowej chemioterapii u chorych $z$ przeciwwskazaniami do intensywniejszej terapii w erze przed wprowadzeniem do praktyki klinicznej inhibitorów proteasomu. Leczenie to było bardzo zbliżone do konwencjonalnego leczenia stosowanego w amyloidozie AL - zwykle złożonego $z$ okresowego podawania małych dawek Mel w połączeniu $z$ PDN. W przypadku amyloidozy zawsze należy brać pod uwagę ograniczenia chemioterapii wynikające z amyloidowego uszkodzenia narządów [2, 10, 20,21]. Ten rodzaj leczenia wykazuje jednak ograniczoną skuteczność i niewielki wpływ na okres przeżycia. Rzadko też prowadzi do całkowitej remisji lub odwrócenia dysfunkcji narządu związanej $z$ obecnością amyloidu.

Obecność złogów amyloidowych u pacjentów z PCM jest niezależnym czynnikiem prognostycznym wysokiego ryzyka niekorzystnie wpływającym na przeżycie [25]. Niektórzy autorzy nie obserwowali jednak tak zdecydowanie niekorzystnego wpływu amyloidozy na skrócenie przeżycia [3]. Ponadto w grupie chorych na PCM $z$ klinicznie bezobjawową amyloidozą leczonych wysokodawkowaną chemioterapią $z$ następowym autologicznym przeszczepieniem krwiotwórczych komórek macierzystych (auto-HSCT, autologous hematopoietic stem cell transplantation) nie obserwowano gorszego przeżycia niż u chorych na PCM bez amyloidozy [20]. Madan i wsp. [11] wykazali, $\dot{z}$ é średni czas przeżycia chorych na PCM $z$ amyloidozą był zróżnicowany. Jednym z czynników, które wpływały na okres przeżycia, była liczba objętych amyloidozą narządów. Dłuższe przeżycia obserwowano u pacjentów bez zajęcia lub $z$ zajęciem jednego narządu niż u chorych $\mathrm{z}$ zajęciem kilku narządów (odpowiednio 13,0 v. 4,3 miesiąca) [11]. Najważniejszym niekorzystnym czynnikiem prognostycznym było zajęcie serca, a zwłaszcza pojawienie się jego niewydolności. Chorzy $z$ tym powikłaniem przeżywali nieco ponad 4 miesiące. W zdecydowanej większości przypadków zgon $\mathrm{w}$ przebiegu amyloidozy następuje $z$ powodu zajęcia serca, często w mechanizmie nagłego zatrzymania krążenia [11, 21]. Dla porównania mediana przeżycia 868 chorych $z$ amyloidozą AL analizowanych w Amyloid Research and Treatment Uniwersytetu w Pavii wyniosła 3,8 roku. Wśród tych chorych 27\% zmarło w pierwszym roku choroby, a $31 \%$ przeżyło 10 lat. W grupie tej zajęcie serca również miało zdecydowanie niekorzystny wpływ na przeżycie [2].

W ostatnich kilku latach w podejściu do leczenia amyloidozy nastąpiły istotne zmiany. Znalazły one wyraz w opracowanych w 2014 roku wytycznych [26]. Zaleca się, aby chorzy na amyloidozę byli leczeni w ramach prób klinicznych, najlepiej w wyspecjalizowanych ośrodkach. Leczenie pierwszej linii powinno być podobne do terapii stosowanej w PCM, ale preferowanym kortykosteroidem powinien być deksametazon. Ze względu na stwierdzaną już wcześniej dużą wrażliwość plazmocytów wytwarzających amyloidogenne łańcuchy lekkie na bortezomib zaleca się wprowadzenie tego leku do leczenia amyloidozy [27]. Obecnie, zważywszy na uzyskiwanie lepszych odpowiedzi i dłuższego czasu przeżycia w badaniach klinicznych, inhibitory 
proteasomu, zwykle w skojarzeniu $z$ lekiem alkilującym i kortykosteroidem, są zalecane w pierwszej linii terapii, zwłaszcza w przypadku konieczności uzyskania szybszej odpowiedzi na leczenie, na przykład przy zajęciu serca, nerek czy przy hipoalbuminemii $[26,28]$. Należy jednak rozważyć zmniejszenie dawki bortezomibu ze względu na większą toksyczność leczenia w amyloidozie niż PCM, a także zachować dużą ostrożność w przypadku zaawansowanej neuropatii (III i IV stopnia). Bortezomib może być też stosowany podskórnie, ale w przypadkach ze znacznymi obrzękami należy go stosować dożylnie [26].

Zmieniło się również podejście do wysokodawkowanej chemioterapii $z$ następowym auto-HSCT. W aktualnych wytycznych terapia ta jest zalecana jako leczenie pierwszej linii u wybranych pacjentów w wieku do 65-70 lat, o ile są spełnione następujące kryteria: wskaźnik przesączania kłębuszkowego (GFR, glomerular filtration rate) ponad $50 \mathrm{ml} / \mathrm{min}$, niskie stężenie biomarkerów sercowych i niewielkie nacieczenie plazmocytowe szpiku przed auto-HSCT. $Z$ takiego leczenia dyskwalifikuje obecność jednego $z$ następujących stanów/objawów: amyloidoza serca (ze stężeniem $\mathrm{N}$-końcowego propeptydu natriuretycznego typu B [NT-proBNP, $N$-terminal pro-B-type natriuretic pepti$d e]>590 \mathrm{pmol} / 1 \mathrm{i} / \mathrm{lub}$ troponiny $\mathrm{T}>0,06 \mathrm{ng} / \mathrm{ml}$ ), ciężka neuropatia, znaczne krwawienie $z$ przewodu pokarmowego $z$ powodu amyloidu, zaawansowana niewydolność nerek, wiek ponad 70 lat, nawroty płynu w opłucnej oraz zły stan ogółny (> 2 pkt. wg ECOG [Eastern Cooperative Oncology Group]) [26]. Obserwowana we wcześniejszych latach znaczna śmiertelność związana $z$ tego rodzaju przeszczepianiem najprawdopodobniej wynikała z niewłaściwego doboru pacjentów.

W kontekście przedstawionego przypadku zwraca też uwagę kwestia leczenia miejscowego i jego ewentualnych następstw. W przypadku amyloidoma najczęściej wykonuje się resekcję guza, również metodą endoskopii. Stosowane są także laseroterapia i radioterapia oraz systemowa chemioterapia $\mathrm{w}$ przypadku wspólistniejących chorób rozrostowych $[4,7,17,22]$. W amyloidozie obserwuje się zajęcie ściany naczyń krwionośnych, ale tylko w pobliżu złogów [9]. Naciekanie naczyń amyloidem może stwarzać ryzyko krwawienia, co obserwowano u opisanego chorego.

U części pacjentów występują nawroty wymagające powtórzenia zabiegu $[4,22]$. Istotnym problemem u pacjenta było też utrudnione gojenie wargi po zabiegu, które skutkowało długo utrzymującym się owrzodzeniem. Upośledziło ono zdolność chorego do przyjmowania pokarmów, spowodowało wyniszczenie i zdecydowanie pogorszyło jakość życia.

\section{Podsumowanie}

Reasumując, przypadek ten pokazuje, że istnieje możliwość wystąpienia w przebiegu PCM zmian amyloidowych o nietypowym umiejscowieniu. Ponadto autorzy zwracają uwagę na kwestię optymalnego leczenia miejscowego tego rodzaju zmian. Zarówno obserwacja tego przypadku, jak i przedstawione piśmiennictwo uświadamiają, że amyloidoza w przebiegu PCM może być częstszym, niż się wydaje, zjawiskiem, a jej objawy mogą imitować inne schorzenia.

\section{Piśmiennictwo}

1. Kyle R., Gertz M. Primary systemic amyloidosis: clinical and laboratory features in 474 cases; Semin. Hematol. 1995; 32: 45-59.

2. Merlini G., Seldin D.C., Gertz M.A. Amyloidosis: pathogenesis and new therapeutic options. J. Clin. Oncol. 2011; 29: 1924-1933.

3. Usnarska-Zubkiewicz L., Hołojda J., Jeleń M. i wsp. The occurrence of AL amyloidosis (light-chain amyloidosis) in patients with multiple myeloma in Lower Silesia Region, Poland. Adv. Clin. Exp. Med. 2014; 23: 235-244.

4. Biewend M.L., Menke D.M., Calamia K.T. The spectrum of localized amyloidosis: a case series of 20 patients and review of the literature. Amyloid 2006; 13: 135-142.

5. Reitboeck J.G., Feldmann R., Loader D. Primary cutaneous amyloidoma: a case report. Case Rep. Dermatol. 2014; 6: 264-267.

6. Fierens J., Mees U., Vanbockrijck M., Hendrikx M. Amyloidoma of the chest wall: a rare entity. Interact. Cardiovasc. Thorac. Surg. 2008; 7: 1194-1955.

7. Paccalin M., Hachulla E., Cazalet C. Localized amyloidosis: a survey of 35 French cases. Amyloid 2005; 12: 239-245.

8. Grunes D., Rapkiewicz A., Simsir A. Amyloidoma secondary to insulin injection: cytologic diagnosis and pitfalls. Cytojournal 2015; 12: 15, doi: 10.4103/1742-6413.161602.

9. Westermark P. Localized AL amyloidosis: a suicidal neoplasm. Ups. J. Med. Sci. 2012; 117: 244-250.

10. Sanchorawala V. Light-chain (AL) amyloidosis: diagnosis and treatment. CJASN 2006; 1: 1331-1341.

11. Madan S., Dispenzieri A., Lacy M.Q. i wsp. Clinical features and treatment response of light chain (AL) amyloidosis diagnosed in patients with previous diagnosis of multiple myeloma. Mayo Clin. Proc. 2010; 85: 232-238.

12. Cranin A., Gross E. Severe oral and perioral amyloidosis as a primary complication of multiple myeloma. Oral Surg. 1967; 23: 158-163.

13. Cahn L. Oral amyloid as a complication of myelomatosis. Oral Surg. 1957; 10: 735-742.

14. Kielts T. Amyloidosis of the buccal mucosa as a diagnostic precursor in multiple myeloma: Report of a case. J. Am. Dent. Assoc. 1964; 69: 701-705.

15. Flick W., Lawrence F. Oral amyloidosis as initial symptom of multiple myeloma: a case report. Oral Surg. 1980; 49: 18-20. 


\section{Hematologia 2016, tom 7, nr 1}

16. Ariyaratnam S., Sweet C., Duxbury J. Low grade multiple myeloma that presented as a labial swelling - a case report. $\mathrm{Br}$. Dent. J. 2005; 199: 433-435.

17. Yu L.L., Heenan P.J., Randell P. Nodular amyloidosis of the lip mimicking an infiltrating neoplasm. Australas. J. Dermatol. 1997; 38: 91-92.

18. Salisbury P., Jacoway J. Oral amyloidosis: a late complication of multiple myeloma. Oral Surg. 1983; 56: 48-50.

19. Raubenheimer E., Dauth J., de Coning J. Multiple myeloma presenting with extensive oral and perioral amyloidosis. 1986; 61: 492-497.

20. Desikan K.R., Dhodapkar M.V., Hough A. i wsp. Incidence and impact of light chain associated (AL) amyloidosis on the prognosis of patients with multiple myeloma treated with autologous transplantation. Leuk. Lymphoma 1997; 27: 315-319.

21. Bahlis N.J., Lazarus H.M. Multiple myeloma-associated AL amyloidosis: is a distinctive therapeutic approach warranted? Bone Marrow Transplant. 2006; 38: 7-15.

22. Mahmood S., Sachchithanantham S., Bridoux F. i wsp. Risk of progression of localized amyloidosis to systemic disease in 606 patients over 30 years. Blood 2013; 122: 3143-3143.
23. Klenke F.M., Wirtz C., Banz Y. i wsp. Multiple myeloma-associated amyloidoma of the sacrum: case report and review of the literature. Global Spine J. 2014; 4: 109-114.

24. Safi S., Op den Winkel J., Schnabel P.A. i wsp. Extended resection of a plasmocytoma of bone and an amyloidoma of the chest wall. Ann. Thorac. Surg. 2013; 96: 2223-2225.

25. Vela-Ojeda J., García-Ruiz Esparza M.A., Padilla-González Y. i wsp. Multiple myeloma-associated amyloidosis is an independent high-risk prognostic factor. Ann. Hematol. 2009; 88; 59-66.

26. Wechalekar A.D., Gillmore A.D., Bird J. i wsp. Guidelines on the management of AL amyloidosis. Br. J. Haematol. 2015; 168: 186-206.

27. Sitia R., Palladini G., Merlini G. Bortezomib in the treatment of AL amyloidosis: targeted therapy? Haematologica 2007; 92: 1302-1307.

28. Venner C.P., Lane T., Foard D. i wsp. Cyclophosphamide, bortezomib, and dexamethasone therapy in AL amyloidosis is associated with high clonal response rates and prolonged progressionfree survival. Blood 2012; 119: 4387-4390. 